DOI:

Марія Багрій, кандидат філологічних наук, докторант ДВНЗ “Прикарпатський національний університет імені Василя Стефаника”

\title{
ВІДОБРАЖЕННЯ У ТВОРЧОСТІ ПИСЬМЕННИКІВ ЗАХІДНОЇ УКРАЇНИ АКТУАЛЬНИХ ОСВІТНІХ ПРОБЛЕМ УКРАЇНСЬКОГО СУСПІЛЬСТВА КІНЦЯ XVIII - 30-ТИХ РОКІВ ХХ СТОРІЧЧЯ
}

Стаття присвячена відображенню актуальних освітніх проблем украӥнського суспільства та вихованню національно-свідомої особистості у творчості письменників Західної України кіния ХVIII cm. 1939 р. Проаналізовано, щуо у вітчизняній педагогіці початку ХХ століття відобразились суперечності між традииійною, офіиійною концепиією щчодо виховання в дусі християнства, народності та підходами, щу брали за зразок західну педагогіку і досвід європейської школи, також не завжди враховували особливості українців як наиії. Проте діяльність письменників-педагогів була спрямована на об'єднання таких рис як прагнення осягнути внутрішній світ дитини, створити умови для ї̈ всебічного розвитку, шанобливе ставлення до неї.

Ключові слова: освіта; начіонально-свідома особистість; Західна Україна; християнство.

Jim. 12.

Mariya Bahriy, Ph.D.(Philology), Doctoral Student State Pedagogical University "Vasyl Stefanyk Precarpathian National University"

\section{REFLECTION OF THE ACTUAL EDUCATIONAL PROBLEMS OF UKRAINIAN SOCIETY AT THE END OF THE 30th YEARS OF THE XXth CENTURY IN THE WORK OF WRITERS OF WESTERN UKRAINE}

The article is devoted to the reflection of the actual educational problems of Ukrainian society and the upbringing of a national conscious personality in the works of writers of Western Ukraine at the end of the 30th years of the XX century - 1939. It is analyzed that in the national pedagogy of the beginning of the XX century there were contradictions between the traditional, official conception of education in the spirit of Christianity, nationality and approaches that took as a model Western pedagogy and experience of the European school, also did not always take into account the peculiarities of Ukrainians as a nation. However, the activities of writers and teachers were aimed at combining such features as the desire to understand the inner world of the child, create conditions for its comprehensive development, respect for it.

By that time, a serious obstacle to the cultural uplift in Western Ukraine was the policy of denationalizing the Ukrainian population, which was carried out by the creators of Austrian and Polish, Romanian and Hungarian states, which in turn had the greatest influence on the organizational activity of the school. Consequently, a young Ukrainian clergy played a significant role in the revival and moral uplift of the Western Ukrainian population, among which there were many educated people who took care of national interests. Western Ukrainian writers and educators were not limited to theoretical considerations concerning the development of Ukrainian schooling. They developed plans for the development and development of the national education system.

In our opinion, the opinion of scientists of the analyzed period deserves attention that pedagogy influences the formation of personality through its introduction into the objective world of cultural values. The most valuable conclusion of the theorists in this direction was the position that the formation of man is not a subjective development of human forces, but an objective process of influence of different content of culture with a view to their participation in creativity. Therefore, the main attention should be paid to stimulating such creative elements in the pupils, which would allow them to enrich the cultural achievements of previous generations.

Keywords: an education; national conscious personality; Western Ukraine; Christianity.

П остановка проблеми. Нова українська література у Західній Україні другої половини XVIII ст., формувалась на ментальній основі. Один із іiі основоположників, Ф. Потушняк, характеризуючи місцеве тогочасне письменство, вказував на його виразний етнографічний характер, соціальну проблематику, реалізм, фольклорні засоби художнього зображення, моралізаторство [7].
Ф. Потушняк глибоко усвідомлював фундаментальнуроль літератури усамоідентифікації та самовдосконаленні етносу: “Література має велику задачу в культурному житті народу. Це вона відкриває нам очі на наше духовне народне я, на ті глибокі скриті тайники, які в житті народу учинкують. Література - це немов чарівний кристал, через який бачимо все те, що лежить скрито в душі народу $<\ldots>$. Без літератури ми 


\section{ВІДОБРАЖЕННЯУ ТВОРЧОСТІПИСЬМЕННИКІВЗАХІДНОЇ УКРАЇНИ АКТУАЛЬНИХ ОСВІТНІХ ПРОБЛЕМ УКРАЇНСЬКОГО СУСПІЛЬСТВА КІНЦЯ ХVIII-30-ТИХ РОКІВ ХХ СТОРІЧЧЯ}

ніколи не пізнаємо себе, ані нас ніхто не пізнає, ані не здобудемо собі відповідне оцінення і в найближчих нам народів" [7].

Мета дослідження - виокремити актуальні освітні проблеми Західної України кінця XVII ст. - 30-тих років XX ст. у творчості тогочасних українських письменників.

Аналіз останніх досліджень і публікацій. Попри те, що письменники Західної України у своїх творах порушували актуальні питання навчання $\mathrm{i}$ виховання дітей та юнацтва, окремого грунтовного і цілісного дослідження цієї наукової проблеми не здійснено. Відображення актуальних освітніх проблем українського суспільства та виховання національно-свідомої особистості у творчості письменників Західної України кінця XVIII ст. 1939 р. частково опрацьовано в працях Г. Білавич, С. Вдовича, Т. Завгородньої, В. Качкана, О. Любара, Л. Потапюка, Ф. Потушняка, М. Романюка, В. Яременка.

Виклад основного матеріалу. Незважаючи на складні суспільні умови, українство західного регіону України викристалізовувало власну ідентичність. Так, в 1820 - 1830-х рр. у Перемишлі біля єпископа Івана Снігурського зібрався гурток письменників і вчених: автор граматики о. Йосиф Левицький, етнограф о. Йосиф Лозинський і філолог о. Антін Лаврівський, які поклали початок культурному відродженню Західної України [5, 315].

Серед представників наростаючого культурнонаціонального руху у боротьбу за українську народну мову виступав гурток молодих львівських богословів на чолі з “Руською трійцею” - Маркіян Шашкевич (1811 - 1843 рр.), Іван Вагилевич (1811 - 1866 рр.) та Яків Головацький (1814 - 1888 рр.). Важливість діяльності цього гуртка важко оцінити, адже важливими джерелами натхнення представників гуртка були національно-визвольні прагнення українського народу, твори відродженої над Дніпром літератури, мовознавчі, історичні та етнографічні роботи діячів українського відродження. Вони активно заохочували читання проповідей в церквах українською мовою та видавничу діяльність рідною мовою (збірна “Зоря”).

Так, наприклад, М. Шашкевич збирав фольклор на рідній Золочівщині. Його поезія була сповнена національно історичною проблематикою (“Руська мова”, “Дайте руки”,"Слово до чтителей руського язика", “Побратим”, “Лиха доля”, “Хмельницького обступлення Львова”, “О Наливайку”, “Болеслав Кривоустий”, “Псалми Русланові”. У 1836 р. М. Шашкевич опублікував брошуру “Азбука і Abecadlo”, спрямовану проти спроб заведення в українській мові латинської абетки. Переклав частину “Слова о полку Ігоревім" та Святого Письма (Свангеліє від Матея і Йоана) народною мовою (1842р.). Посмертно Яків Головацький видав "Читанку” М. Шашкевича для малих дітей (1850р.). I. Вагилевич обрав для свого вивчення культурні традиції сіл Калущини, Стрийщини, Сколівщини. Я. Головацький обійшов майже всю Галичину, Закарпаття й значну частину Буковини. Митці відкривали для громадськості історичну значимість українського народу [5, 218].

Беззаперечним фактом прийнято вважати, що перші спроби підняти із занепаду та “протоптати стежку до письменства" рідним словом на Західній Україні зробили М. Шашкевич та I. Вагилевич, які під впливом творів Шафарика, Караджича, Котляревського, Максимовича та інших, із своїми однодумцями зробили перші кроки у цьому напрямку. Значною подією у цій роботі став літературний альманах “Русалка Дністрова". Адже цей альманах став сміливим викликом проти національного гноблення та консерватизму.

Завдяки активній діяльності товариства на сторінках альманаху вперше в історії українського суспільного руху Західної України прозвучала ідея возз'єднання всіх українських земель у складі майбутньої федерації. Згодом від культурномовних питань гуртківці перейшли до соціальноекономічних і політичних. Діяльність учасників “Руської трійці” сприяла підвищенню освітнього рівня і пробудженню національної свідомості народу Західної України [6].

У педагогічних поглядах "Руської трійці" послідовно обстоюється необхідність українського національного виховання й освіти в Галичині та на Західному Поділлі. Педагогічні погляди "Руської трійці” мали колосальний вплив на формування нової генерації українських учителів, на дальший розвиток прогресивної педагогічної думки на Західному Поділлі [5, 236].

Варто зауважити, що з середини ХІХ століття почали поширюватись на Україні ідеї емансипації. В Галичині Наталя Кобринська створила жіночий гурток “Товариство руських жінок” і стала піонером жіночого руху. А згодом разом з Оленою Пчілкою упорядкувала літературний альманах “Перший вінок”, де були зібрані твори відомих митців: Климентини Попович, Ольги Франко, Анни Павлик, Михайлини Рошкевич, деякі з їхніх творів зображали українські звичаї. Юна Леся Українка, яка дебютувала на сторінках альманаха, надрукувала дві поезії: “Любка”, "На зеленому горбочку”. Михайло Павлик, Іван Франко, Михайло Драгоманов підтримували та сприяли 


\section{ВІДОБРАЖЕННЯ У ТВОРЧОСТІ ПИСЬМЕННИКІВЗАХІДНОЇ УКРАЇНИ АКТУАЛЬНИХ ОСВІТНІХ ПРОБЛЕМ УКРАЇНСЬКОГО СУСПІЛЬСТВА КІНЦЯ ХИІІІ -30-ТИХ РОКІВ ХХ СТОРІЧЧЯ}

творчому розквітові літературних спроб жінок [11, 107].

Саме в цей період завдяки просвітницьким ідеям письменників-педагогів вдалося виробити теоретичні основи національної освіти та втілити основні їх положення в практику виховання української молоді. У цьому процесі, взяли активну участь жінки-освітяни Уляна Кравченко, Марійка Підгірянка, К. Малицька, Є. Ярошинська, І. Блажкевич, К. Попович. Цінність діяльності зазначених письменниць підсилюється ще й тим, що вони у своїх літературних творах зафіксували історичний хід подій означеної епохи, залишивши цілу низку художніх образів учнів, учителів, спогади про суспільно-історичні процеси аналізованої доби.

Отже, найбільш характерними поглядами західноукраїнських письменників-освітян досліджуваної доби є:

1. Реалізація природних обдарувань залежить від сили волі. Брак волі, пасивність, лінивство гальмують реалізацію природних задатків дитини (С. Балей).

2. Природній обдарованості дитини має адекватно відповідати організація навчальновиховного процесу (I. Карбулицький, О. Попович, В. Ратальський, I. Ющишин);

3. Здатність власного думання, творчість, жива діяльність випливають із природної потреби дитини (О. Барвінський, Г. Врецьона, О. Духнович, С. Смаль-Стоцький, Ю. Федькович, І. Франко);

4. Фізичне і статеве виховання має сприяти природному розвиткові дитини (І. Бажанський, О. Іванчук, С. Кусевич, М. Макух, Р. Перфецький, I. Франко);

5. Естетичне виховання повинно починатися 3 перших днів життя дитини, воно має плекати у дитини відчуття краси, добра, радості. Особлива роль в естетичному вихованні належить пісні (В. Барвінський, І. Бартошевський, О. Колесса) [2].

Австрійські освітні реформи середини та другої половини ХІХ ст. (1848, 1869 - 1872 рр.) певною мірою сприяли вирішенню потреб шкільних закладів. Н. Кобринська в 1891 р. оприлюднила ідею українських шкільних закладів. Ця ідея знайшла обгрунтування і розвиток у проекті Статуту товариства “Охоронка” (1893р.). Серед організаторів суспільного виховання дошкільнят того часу виділились М. Білецька, М. Грушевська, Г. Шухевич та ін.

С. Смаль-Стоцький вважав, що необхідно давати селянам добру освіту, бо лише освічений народ зможе досягти високого життєвого рівня. Для розбудови української школи педагог активно взявся за вивчення світового досвіду освіти для дорослих. Він уважав, що від народної інтелігенції багато в чому залежить культурна й економічна сила народу, вона “...мусить зібрати всі сили умислові на те, аби оту працю підперти, зробити iï видатною, постаратися о те, аби та праця не марнувалася; одним словом, інтелігенція народна повинна зайнятися докладною організацією праці народної. Це дасться осягнути через всякі товариства наукові, літературні, просвітні, через всякі стоваришення економічні та ін." [8, 121].

Варто зазначити, що західноукраїнські письменники-педагоги не обмежувалися викладом теоретичних міркувань щодо розвитку українського шкільництва. Вони розробляли плани розбудови та розвитку системи національної освіти. Так, наприклад, показовим у цьому питанні були викладені видатним освітнім і педагогічним діячем I. Ющишиним. Він подав "Проект" на зміну державного шкільного закону з дня 14 мая 1869 року (1913 р.), де були сконцентровані ідеї не лише самого автора, але й широкого загалу галицьких педагогів, практичні пропозиції реалізації національного шкільництва.

На нашу думку, значну роль у цей період відігравали шкільні підручники. Так, у кінці XIX ст. з'явилися шкільні підручники для початкових класів на українській мові. Переважно це були граматики української мови та читанки (книжки М. Шашкевича, Я. Головацького, О. Духновича, О. Барвінського та ін.). Почали друкуватися перші українські підручники й для середніх шкіл.

Українська школа Західного регіону потребувала твердого національного фундаменту. Тому М. Грушевський, О. Іванчук, О. Макарушка, I. Ющишин важливим шляхом формування національної свідомості вважали насичення змісту освіти історичними традиціями, знаннями культурно-історичної спадщини (але у єдності 3 загальнолюдськими цінностями), що буде сприяти формуванню в учнів почуття єдності 3 усім народом, а в перспективі - 3 людством.

Видатні письменники-педагоги Г. Врецьона, М. Галущинський, О. Іванчук, В. Ільницький, А. Крушельницький, Ю. Партицький, І. Петрів та багато інших старанно вивчали, аналізували та використовували твори класиків світової педагогічної думки, знаходячи там підтвердження своїх поглядів на принципи та шляхи розбудови національної школи. Довгий час побудова національної школи пов'язувалася, перш за все, $з$ введенням української мови як викладової, що мало тоді дуже важливе значення. Як стверджував М. Грушевський, навчання в школі має проводитися українською мовою і на 


\section{ВІДОБРАЖЕННЯ У ТВОРЧОСТІ ПИСЬМЕННИКІВЗАХІДНОӤ УКРАЇНИ АКТУАЛЬНИХ ОСВІТНІХ}

ПРОБЛЕМ УКРАЇНСЫКОГО СУСПІЛЬСТВА КІНЦЯ ХVIII-30-ТИХ РОКІВ ХХ СТОРІЧЧЯ

українській основі, “бо інакше як на своїй народній основі не стане наш народ просвіченим, не вийде 3 теперішньої темноти, злиднів і пониження" $[1,113]$.

На нашу думку, особливої уваги заслуговує діяльність Юліана Романчука - представника нової генерації української інтелігенції Західної України, що вийшла на історичну арену в останній чверті XIX ст. Працюючи на педагогічній ниві як викладач єдиної української середньої школи, він виявив себе як прекрасний педагог, знавець класичних мов, чудовий вихователь своїх учнів. Саме в цей період свого життя Ю. Романчук почав укладати шкільні підручники українською мовою, підготував до друку і видав "Руську читанку для четвертої кляси народних шкіл” і дві частини “Читанки для нищих середніх шкіл”. 3 його ім'ям пов'язана праця провідних національнокультурних інституцій Галичини, передусім Товариства "Просвіта".

Наш інтерес привертають й роботи О. Партицького. Аналізуючи його педагогічну спадщину, 3 упевненістю можемо стверджувати, що провідною тематикою його міркувань стали проблеми виховання молоді. Формуючи основи виховного ідеалу підростаючого покоління, педагог опирався на родинне-сімейне виховання дітей. Свідченням цього $\epsilon$ те, що практично всі надруковані О. Партицьким педагогічні праці присвячені питанням виховання підростаючого покоління та визначальній ролі сім’ї-родини в даному процесі. Саме на шпальтах "Газети школьної”, педагог ділився своїми міркуваннями iз педагогами-сучасниками.

I. Франко формування художньо-естетичних смаків у молоді вбачав у безпосередньому залученні її до вивчення народної пісенної творчості, побуту, культури, традицій та звичаїв свого краю. Акцентуючи увагу на тісному зв'язку художньої літератури 3 усною народною творчістю, він наголошував, що “виразних і тривких границь між словесністю і писемством нема, бо те, що раз затверджено на письмі, може переходити знов в усну традицію, в пам'ять і життя нових поколінь, i, навпаки, те, що вчора зложилося в усній передачі або існувало від віків у пам'яті людей, сьогодні може бути закріплене письмом" [9, 7 - 8].

I. Франко наголошував, що “всі здобутки культури і науки сталися власністю народу”. Він критикував тогочасну систему виховання та навчання у школах, що обмежувалася набуттям школярами навичок читання і письма; закликав дати дітям “справжнє розумове живлення"; звертав увагу “на необхідність систематично навчатись усіма засобами” [10, 18$]$.
Також письменник щиро обурювався, що Австро-Угорська влада прагне створити окремі школи для дітей селян, ремісників, чиновників, дбаючи лише про те, щоб “кожен швець повинен залишитися біля своїх колодок, і ніхто не повинен пробувати вибитися $з$ того прошарку, з якого походить" [12].

В той же час, у вітчизняній педагогіці початку ХХ століття відобразились суперечності між тради-ційною, офіційною концепцією щодо виховання в дусі християнства, народності та підходами, що брали за зразок західну педагогіку і досвід європейської школи, також не завжди враховували особливості українців як нації. Проте, діяльність письменників-педагогів була спрямована на об'єднання таких рис як прагнення осягнути внутрішній світ дитини, створити умови для її всебічного розвитку, шанобливе ставлення до неї.

Так, в працях галицьких науковців Г. Врецьони, I. Дуба, О. Іванчука, В. Раталського та інші зустрічається, теоретичне обгрунтування мети школи, що почала ототожнюватись із формуванням національної свідомості, формуванням українця-патріота. Ця мета, на думку галицьких письменників-педагогів, повинна була знайти вираз у наповненні школи “національним духом" не тільки за формою, але й за змістом. Пріоритетним завданням школи в педагогічному процесі стало виховання. Провідними принципами національного виховання вважалися народність, природовідповідність, гуманізація, демократизація.

Письменники-педагоги Західної України на початку XX ст., який вони називали епохою національного ренесансу, багато уваги приділяли розробці теорії змісту освіти. Вони виходили 3 того, що школа мусить “жити і розвиватися під промінням національної ідеї: усе в ній мусить бути овіяне національним духом, а короною їі діяльності повинні бути свідомі національно члени народу" $[4,23]$.

Серед головних течій соціальної педагогіки Західної України науковці називали: педагогіку чисто соціальну (їі представниками були П. Бергеман, Дж. Дюї, В. Кілпатрік та ін.), педагогікугромадянського виховання (Я. Сосницький), педагогіку націоналістичну (Е. Кріек), народну педагогіку (3. Багіцький, В. Боровський, Л. Зажецький, С. Пігон, П. Преговський), суспільну педагогіку (Я. Давід, А. Добровольський, С. Карпович, К. Корнілович), ідеалістичну педагогіку (П. Наторп), педагогіку культури (Г. Кершенштайнер) $[4,55]$.

Увага письменників-педагогів саме до 


\section{ВІДОБРАЖЕННЯ У ТВОРЧОСТІ ПИСЬМЕННИКІВЗАХІДНОЇ УКРАЇНИ АКТУАЛЬНИХ ОСВІТНІХ ПРОБЛЕМ УКРАЇНСЬКОГО СУСППЛЬСТВА КІНЦЯ ХИІІІ -30-ТИХ РОКІВ ХХ СТОРІЧЧЯ}

визначених течій пояснюється актуалізацією проблем національного та державно-суспільного виховання тих часів. Серед напрямків, що можна виділити в педагогіці початку ХХ ст., з'явився такий напрям, як народна педагогіка (Л. Зажецький, 3. Баліський, П. Преговський та ін.). В ній розроблялися методи, принципи та засоби, за допомогою яких молодь готувалася до служіння своєму народові та рідній культурі. Іншими словами, польськість мала бути підставою виховання відданих польській державі громадян.

Так, наприклад, М. Галущинському належить основна заслуга у розробці теоретикометодичних основ педагогіки для дорослих у Галичині на початку XX ст. Про це свідчить його підручник "Позашкільна освіта" [3] - перший в історії педагогіки, в якому автор обгрунтував термін “позашкільна освіта" i, проаналізувавши форми, методи та мету освітньої праці у світі, провів паралель із розвитком освіти дорослих серед українського народу, зокрема ознайомив читача з основами бібліотечної справи. Він вважав, що позашкільна освіта проявляється у різних сферах: через школу, університет, виклад, самоосвітній гурток, через мистецтво, книгу i книгозбірню, і що весь тягар просвітньої роботи лежить на свідомих людях доброї волі.

Висновки. Отже, офіційна освітня політика західноукраїнських земель була спрямована в першу чергу на виховання молоді. У 20-х роках XX ст. акцент робився на національній ідеї, а в кінці 20-х років - на державницькій ідеї, що вимагало посилення громадянського виховання; на здійснення державної монополії на виховання підростаючих поколінь; на структурну гармонізацію системи освіти; на уніфікацію середньої школи; рівневе піднесення освіти; вдосконалення системи визначення прав осіб, які отримали педагогічну освіту в закладах підготовки вчителів, на роботу в народних школах; на полонізацію українців.

Таким чином, можна виокремити внесок українських письменників у теорію і практику освіти дітей та дорослих:

- філософсько-педагогічній теорії взаємозв'язку детермінізму й індетермінізму, що дають можливість проаналізувати процес становлення ідей національної ідентичності, педагогіки не лише 3 погляду відомих результатів, але й їх незавершеності (І.Я. Франко, І. Ющишин та ін.);

- філософсько-педагогічній теорії взаємозв'язку національного й загальнолюдського у формуванні цінностей особистості, пробудження самосвідомості народу (А.І. Волошин, О.В. Духнович та ін.);
- історико-педагогічній теорії співвідношення об'єктивного і суб' єктивного, факту й теорії в науці (М.С. Грушевський, І.П. Крип'якевич, Ф. Прокопович та ін.);

- психолого-педагогічній теорії особистості та іiï розвитку в процесі діяльності (С. Балей, В. Барвінський, О. Попович, С. Смаль-Стоцький та ін.).

Окремі елементи педагогіки в працях I. Вагилевич, Я. Головацький, А. Добрянський, I. Лаврівський, Й. Лозинський, І. Могильницький, I. Снігурський, М. Шашкевич (Галичина); М. Балудянський, Ю. Гуца-Венелін, О. Духнович, П. Лодій, I. Орлай, І. Раковський, І. Чургович (Закарпаття); В. Андрухович, Т. Блажевич, О. Бурачинський, Я. Воробкевич, К. Дуглір, I. Онишкевич, О. Семака, Ю. Федькович, В. Янович (Буковина) та ін.

\section{ЛІТЕРАТУРА}

1. Бокань В., Польовий Л. Історія культури України. Київ, 1998.232 с

2. Вдович С.М. Впровадження ідей гуманної педагогіки Галичини (кінець XIX - початок XX століття) в сучасну університетську підготовку вчителя. Педагогіка і психологія професійної освіти. 1998. №2. C. $172-177$.

3. Галущинський М. Позашкільна освіта : (народини, - освітні установи, - організаційні форми, - мета). Львів, $1927.47 \mathrm{c}$

4. Завгородня Т.К. Теорія і практика навчання в Галичині (1919 - 1939 роки): монографія. 2007.392 с.

5. Любар О. О., Стельмахович М. Г., Федоренко Д. Т. Історія української школи і педагогіки : навч. посіб. Київ, $2006.447 \mathrm{c}$.

6. Потапюк Л. Ідеологічні та соціально-педагогічні причини виникнення i розвитку культурнопросвітницьких громад на Західній Україні (друга половина XIX - початок XX ст.). Витоки педагогічноі майстерності. 2015. Випуск 15. С. 252-257

7. Потушняк Ф., Петровцій І. Рідна література. Ворожки Осійських босоркань / Упорядкував I. Петровцій. 2011. С. 461-462.

8. Смаль-Стоцький С. Політика реальна. Буковина. 1896. Ч. 85.

9. Франко І. Теорія і розвій історії літератури. Т. 40. Київ, 1976.440 c

10. Франко I. Твори : в 50 т. Том 19. Київ, 1976.220 с.

11. Франко І. Українська альманахова література. І. Франко. Зб. творів : у 50 т. Т. 27. Київ, 1984.

12. Die Zeit. 1901. № 356. C. 18-25.

\section{REFERENCES}

1. Bokan, V. \& Polovey, L. (1998). Istoriya kultury Ukrayiny [History of Culture of Ukraine]. Kyiv, 232 p. [in Ukrainian].

2. Vdovich, S.M. (1998). Vprovadzhennya idey humannoyi pedahohiky Halychyny (kinets XIX - pochatok XX stolittya) v suchasnu universytetsku pidhotovku 
vchytelya [Implementation of ideas of humane pedagogics of Galicia (end of the XIX - the beginning of the twentieth century) in modern university teacher training]. Pedagogics and psychology of vocational education. No.2, pp.172-177. [in Ukrainian].

3. Galushchinsky, M. (1927). Pozashkilna osvita : (narodyny, - osvitni ustanovy, - orhanizatsiyni formy, meta) [Out-of-school education: (peoples, - educational institutions, - organizational forms, - purpose)]. Lviv, $47 \mathrm{p}$. [in Ukrainian].

4. Zavgorodnya, T.K. (2007). Teoriya i praktyka navchannya $v$ Halychyni (1919 - 1939 roky): monohrafiya. [The theory and practice of teaching in Galicia (1919-1939): monograph]. 392 p. [in Ukrainian].

5. Lyubar, O. O., Stelmakhovich, M.G. \& Fedorenko, D.T. (2006). Istoriya ukrayinskoyi shkoly i pedahohiky: navch. posib. [History of Ukrainian School and Pedagogy: Teach. Manual]. Kyiv, 447 p. [in Ukrainian].

6. Potapiuk, L. (2015). Ideolohichni ta sotsialnopedahohichni prychyny vynyknennya i rozvytku kulturnoprosvitnytskykh hromad na Zakhidniy Ukrayini (druha polovyna XIX - pochatok XX st.) [Ideological and sociopedagogical reasons for the emergence and development of cultural and educational communities in Western Ukraine (second half of the XIX - early XX centuries)]. Origins of pedagogical skill. Issue 15, pp. 252-257. [in Ukrainian].

7. Patushnyak, F. \& Petrovich, I. (2011). Ridna literatura [Native literature]. Enemies of the Ossey bourgeoisie. (Ed.).I. Petrovtsy, pp. 461-462. [in Ukrainian].

8. Smal-Stotsk, S. (1896). Polityka realna [Politics is real]. Bukovina, p. 85. [in Ukrainian].

9. Franko, I. (1976). Teoriya i rozviy istoriyi literatury [Theory and Literacy History]. Vol. 40. Kyiv, 440 p. [in Ukrainian].

10. Franco, I. (1976). Tvory: v $50 t$. [Works: 50 t.]. Vol. 19. Kyiv, 220 p. [in Ukrainian].

11. Franko, I. (1984). Ukrainska almanakhova literatura [Ukrainian Almanac Literature]. Works in: 50 vol; Vol. 27. Kyiv. [in Ukrainian].

12. Die Zeit. (1901). No. 356, pp. 18-25. [in Deutch].

Стаття надійшла до редакції 15.03.2019

УДК 796.011.3:373.3

DOI:

Олена Сакалюк, кандидат педагогічних наук, старший викладач кафедри початкової освіти Київського університету імені Бориса Грінченка

\section{ФОРМУВАННЯ ЗДОРОВ'ЯЗБЕРЕЖУВАЛЬНОЇ КОМПЕТЕНТНОСТІ УЧНІВ ПОЧАТКОВИХ КЛАСІВ ЗАСОБАМИ КІНЕЗІОЛОГІЧНИХ ФІЗКУЛЬТХВИЛИНОК}

У статті розглядається проблема важливості формування здоров 'язбережувальної компетентності учнів початкових класів засобами кінезіологічних фізкультхвилинок; виокремлюється класифікація здоров'язбережувальних технологій; висвітлюються сучасні підходи до інтерпретації поняття “здоров'язбережувальна компетентність” в умовах реформування системи освіти України; пропонується комплекс кінезіологічних фізкультхвилинок для формування здоров'язбережувальної компетентності молодиих школярів.

Ключові слова: здоров'язбережувальна компетентність; здоров'язбережувальні технології; кінезіологічні вправи.

Jim. 10.

Olena Sakalyuk, Ph.D.(Pedagogy), Senior Lecturer of the Primary Education Department Borys Hrinchenko Kyiv University

\section{FORMATION OF HEALTHCARE-SAVING COMPETENCE OF PRIMARY SCHOOL STUDENTS BY THE MEANS OF KINESIOLOGICAL EXERCISE MINUTES}

The article deals with the problem of the importance of the formation of health and preserving competence of primary school students by means of kinesiological exercise minutes; singles out the classification of healthcaresaving technologies; highlights the modern approaches to the interpretation of the concept "health-saving competence" in the context of reforming the education system of Ukraine; offers a complex of kinesiological exercise minutes for the formation of health-saving competence of junior pupils.

The article states that one of the means of solving the above tasks is the use of health-saving technologies, without which the educational process of a modern educational institution became impossible. It is also very important that each technology has a health-improving orientation, and used in the complex health protective activities would form a sustainable motivation for younger students in a healthy way of life. The process of formation of healthcare-saving competence in primary school students can not be avoided without the use of kinesiological exercise minutes. With the help of kinesiology, health improves, basic mental processes are optimized (memory, 